Phronesis vol. XXXIII, Nr. 1, 1988

\title{
Aristotle's Courageous Passions
}

\author{
Stephen Leighton \\ Queen's University, Kingston
}

How do the courageous feel upon the field of battle? Aristotle's answer concerns fear and confidence, but stating his position with precision is difficult, not only because Aristotle does not approach the issue in this way, but also because his thoughts that do bear on an answer are limited and seem discordant. Although these latter difficulties could be dismissed as due to carelessness or inattention, a more telling explanation has to do with the intrusion of certain ethical doctrines, forcing Aristotle in different directions. But this diagnosis does not preclude the hypothesis that there is one answer to the question which Aristotle does or should favour. To give an account of this answer, and of the diagnosis, is the object of my paper.

If one is concerned about courage as it bears upon one's emotional life, is there any reason to restrict the question to the battlefield? Socrates in the Laches (191dff) seems to think that courage is found in many settings. For him the question is appropriately put with regard to people tossed on a storm swept sea, suffering illness or poverty, and, perhaps, struggling with money or intellectual matters. Aristotle, however, restricts questions of courage to the battlefield. He does so not because he thinks that situation is most likely to reveal the relevant feelings (though doubtless he thinks this also), but because, strictly speaking, only in this setting is courage found. As a philosopher struck by the homonymy and paronomy of expressions, and what Owen has called "focal meaning," Aristotle deems the extension of 'courage' to be narrower than Plato had allowed. Rather than searching for what is common to all instances of courage or all the utterances of 'courage,' Aristotle turns to the paradigm of courage, to courage in its most perfect and noble form. That paradigm is to be found upon to the battlefield, though 
even here, paradigm versus derivative cases are to be distinguished. ${ }^{1}$ To get a grip on Aristotle's view, then, the question must be set and answered in terms of the paradigm. Once answered, of course, it would be interesting and appropriate to apply the considerations Aristotle raises to the more extensive terrain that Plato works (cf. Politics $1334 \mathrm{a} 22)^{2}$

One approach to the question would be to observe that when injured the courageous, like anyone else, are in pain; when victorious, like anyone else, they are ecstatic. But I do not mean my question in this way. Rather I mean the question to concern whether from Aristotle's thoughts anything follows about the spirits of the individual acting courageously by virtue of being courageous.

A different approach to the question would be a psychological-sociological one, involving introspection and observations concerning the acts of the courageous upon the field of battle. Such consultation of what people commonly say and do Aristotle would find valuable. Presumably, his inclusion of fear and confidence is in part explained by such an appeal to the phenomena. ${ }^{3}$ But this approach will not resolve the matter for

\footnotetext{
1 The justification for thinking that upon the battlefield the paradigm will be found would seem to involve genetic considerations about where the notion of courage arises, where it is most nobly set, where the term is used (say, literary and pedestrian discussions), as well as considerations about the distinctiveness of this excellence in comparison with related excellences, e.g. temperance, practical wisdom. Unless otherwise indicated, references are to the Nicomachean Ethics; translations from the Nicomachean Ethics are by D. Ross (revised by J.L. Ackrill and J.O. Urmson, Oxford University Press, 1986); all other translations are from J. Barnes' Revised Oxford Translations of The Complete Works of Aristotle (Princeton University Press, 1984).

${ }^{2}$ In Metaphysics gamma Aristotle argues for a science of being qua being, not because there is one sense of being, but because of the relationship of different senses to a primary sense (10005a5-11). Similarly, an Aristotelian investigation of courage should allow that the Socratic extension is something that one can discuss intelligently, though it requires the methodology suggested here, and it needs to be realized that one would be talking of a derivative notions of courage.

${ }^{3}$ In interviews with people who act courageously one usually hears more talk of fear than confidence. Aristotle also thinks courage mostly has to do with matters of fear (1117a29), and his discussions reflect this. Since Aristotle's own remarks on confidence are minimal, I too shall
} 
Aristotle (nor, I suspect, for us). A philosophically naive appeal to experience could well be undermined or altered by answers to questions about the nature of courage, courageous acts, etc. --as the issue of courage's extension indicates. Thus support for and interpretation of the appeal to the phenomena requires theoretical backing.

Consider how Aristotle's thoughts about courage as a virtue and thereby a mean bear on our question. 'With regard to feelings of fear and confidence courage is the mean.' (1107a31- b2, cf. 1115a6-7, 1116a10-12, 1109a20-24). Yet claiming that courage is a mean concerning fear and confidence does not entail that either or both of these passions must be felt when acting courageously. Virtue, as a certain sort of state (1106a11), is a certain sort of disposition, while fear and confidence are certain sorts of occurrences. ${ }^{4}$ As a state, a disposition, rather than something occurrent, virtue itself is not something that involves feelings. Of course, the manifestations of this state (virtue) require occurrences. But since virtue is a mean state having to do with actions as well as passions (1106b16-18, 1109a20-24), and since to act courageously requires actions, it does not follow that the manifestations of courage upon the battlefield require the passions. For the required actions themselves may suffice for the manifestations of a courageous disposition (cf. 1114b26-30). Certainly, the passions that have to do with courage must have some manifestations, but it is possible that these manifestations are appropriate to reflection upon courses of action, the development or habituation of virtue, etc., rather than upon the battlefield. Here, then, there is insufficient reason to suppose that because virtue is a mean in regard to feelings of fear and confidence the courageous upon the battlefield do or do not feel both or either passions.

Various passages suggest that the matter is not as open as just claimed. For

concentrate on fear. But see J.L. Stocks' plea on behalf of what he calls cheer in "The Test of Experience" (Mind 1919), and A. Duff's position that only through the transformation of fear by confidence does the state become an excellence ("Aristotelian Courage" Ratio, 1987).

4 That states (hexis) are to be understood dispositionally is suggested by Categories chapter 8, as well as their characterization in 2/5; that passions (pathē) such as fear and confidence are to be understood occurrently is suggested by the examples used and the role of pleasure and pain in their characterization in $2 / 5$. 
example, when contrasting cowardice and intemperance, Aristotle observes that while cowardice the state is without feeling, the manifestation of it involves pain (1119a25ff). This is some evidence that the courageous on the battlefield likewise feel some passion. Yet whether this extrapolation should be generalized is hard to say: Aristotle's descriptions of the manifestations of courage are infrequent, and, as I shall later show, offer sufficiently diverse views such that one does not know whether such remarks are merely ad hoc speculations or in some way represent Aristotle's received view on the matter. Some confirmation on what Aristotle's approach is is needed. ${ }^{5}$

Perhaps, a more detailed exposition of the mean will resolve the matter. One explanation is the following:

...virtue must have the quality of aiming at the intermediate. I mean moral virtue; for it is this that is concerned with passions and actions, and in these there is excess, defect and intermediate. For instance, both fear and confidence and appetite and anger and pity and in general pleasure and pain may be felt both too much and too little, and in both cases not well; but to feel them at the right times, with reference to the right objects, towards the right people, with the right motive, and in the right way, is what is both intermediate and best, and this is characteristic of virtue. Similarly, with regard to actions also there is excess, defect, and the intermediate. Now virtue is concerned with passions and actions, in which excess is a form of failure, and so is defect, while the intermediate is praised and is a form of success; and being praised and being successful are both characteristics of virtue. Therefore virtue is a kind of mean, since, as we have seen, it aims at what is intermediate. (1106b14-29)

Since virtue and thereby courage is developed through habituation (cf. 1103a16, 32-b2) in regard to the relevant actions and passions (1104a27-b3), the acquisition of the virtue courage would seem to involve learning to act and to feel certain passions in the right way, at the right time... A plausible gloss on this is that both in the development and,

5 One might interpret certain statements of the mean to indicate that virtue is a mean between feelings and actions (e.g. 1107a31- b2). This suggests that the relevant feelings must be present when virtue is present, including the battlefield. For, on this understanding, virtue itself is a specifiable feeling and action. Such interpretation, however, would be misinterpretation, as Aristotle's efforts to distinguish virtues from passions would indicate (2/5). Moreover, most statements of the doctrine of the mean make clear that virtue is a mean concerning feelings and actions, not implying that virtue is a feeling or action. 
more importantly, in the manifestation of courage the relevant passions (fear and confidence) come into play. What exactly to feel them at the right time, in the right place... comes to is not evident but their requirement upon the battlefield seems likely. If so, the correct answer to our initial question is that both confidence and fear are felt upon the battlefield.

Yet we still lack sufficient reason to adopt this interpretation. For it remains possible that the right occasion for feelings of fear or confidence is not the battlefield. Some commentators rightly point out that Aristotle's characterization of the mean should not to be read as suggesting an evening out or leveling of feeling between extremes, virtue as mediocrity. ${ }^{6}$ Rather, virtue allows for extremes (but not excesses or defects) of feeling, including no feeling whatsoever. Thus to feel fear or confidence at the right time, at the right things, towards the right people may be at times other than while acting courageously, perhaps in anticipation of or reflection upon battle, or whilst developing the virtue. Hence though the drift of Aristotle's thought suggests that the fear and confidence are to be felt on the occasion of courageous action, to draw the conclusion that it is upon the battlefield that these feelings are had requires further support.

That support is had by further reflection on the role Aristotle accords to habituation. According to Aristotle moral virtue is not had by nature, but developed through a process of habituation (1103a16-20), in which the virtue arises out of like activities (1103b21). The habituation of courage has to do with being habituated to feel fear and confidence and to act appropriately in the presence of danger (1103b16-17). The most plausible interpretation of this is that one becomes courageous by learning to deal with situations that bring forth feelings of fear and confidence such that one both acts and feels appropriately in such situations. ${ }^{7}$

\footnotetext{
${ }^{6}$ See for example, J.L. Ackrill, Aristotle the Philosopher, pp. 136-7; J.O. Urmson, "Aristotle's Doctrine of the Mean," in A. Rorty (Ed.) Essays on Aristotle's Ethics, especially pp. 160-1. Consider also passages such as 1109a25-30, 1109b15-18.

${ }^{7}$ Aristotle warns of dangers here. The education of the Lacedaimonians focuses too much on victory in war, leaving a people unable to deal with peace (Politics 1271b4ff); their education
} 
This alone still might not seem to imply anything about virtuous action itself. For one might argue that the conditions for becoming need not be the conditions of being. Thus even if the relevant passions must be felt in the habituation of virtue in relevant situations, they are not thereby present in the manifestations of virtue. Aristotle, however, does not divorce conditions for becoming from those of being in the way just suggested. Indeed, it is antithetical to his treatment of the habituation of virtue that the nature of generation be divorced so from the nature of the generated. Rather Aristotle holds that the same kinds of activity that produce a state are also found in the manifestation of that state.

But not only are the sources and causes of their [virtues] origination and growth the same as those of their destruction, but also the sphere of their actualization will be the same; for this is also true of the things which are more evident to sense, e.g. of strength; it is produced by taking much food and undergoing much exertion, and it is the strong man that will be able to do these things. So too it is with the virtues; by abstaining from pleasures we become temperate, and it is when we have become so that we are most able to abstain from them; and similarly too in the case of courage; for by being habituated to despise things that are fearful and to stand our ground against them we become brave, and it is when we have become so that we shall be most able to stand our ground against them. (1104a27-b4).

The detailed application of this to courage remains unclear. Nevertheless, Aristotle's claim about the habituation of courage in terms of passions and actions (noted above, cf. 1117a30-35) holds not only for the development of courage, but also for its manifestations. Herein is confirmation that the earlier passage discussing the nature of cowardice was not an aberrant remark, but representative of one feature of Aristotle's thought. His position on virtue, courage and their development requires that the courageous on the battlefield should feel fear and confidence --either both or sometimes

brutalizes the youth, creating a fierce rather than gentle (and more effective) character (Politics 1338b10ff). Aristotle recommends an over all education in reading and writing, gymnastic, music and drawing (Politics 1337b20ff). The concern is the noble (Politics 1338a30); war is for the sake of peace (Politics 1333a36); one is to come to delight in and be pained by what one ought (1104b11). 
one, sometimes the other. ${ }^{8}$

Consider the question from a different perspective. Any account of Aristotle's treatment of the passions should cohere with his distinction between virtue and vice, versus continence and incontinence. Whereas the former involve choice (1005b29-6a5), the incontinent act contrary to choice (1151a5-7). In particular, continence and incontinence, feature resistance and conquering of certain bodily pains and pleasures (1154b19-35, 1150a25-31, 1166b6-10, De Anima 433b5-8). The continent are successful in their resistance and struggle, acting as do the virtuous (the temperate); the incontinent are unsuccessful in their resistance and struggle and act as do the vicious (the intemperate). ${ }^{9}$ In contrast, the virtue relevant to these pains and pleasure, temperance, doesn't involve the internal strife of the continent and incontinent (1148a10-17): it has no bad pleasure to deal with (1152a2); no pain arises by the denial of the bodily pleasures; indeed the denial itself is enjoyed (1104b7).

Although Aristotle doesn't deploy the contrast between the virtuous and continent, the vicious and the incontinent in other areas, its application is legitimately extended to them (cf. 1147b27-35, 1149a21-4). Moreover it illuminates morally significant differences between kinds of characters.

When the development of character through habituation is brought to bear on the distinction between the continent in respect of fear (cf. 1147b27-8a10) and the courageous, the following picture emerges. One thing learned by habituation is how to "handle" one's fear. The courageous "handle" it well in the sense that like the cowardly they are not disturbed by their passions; struggle is not necessary. The two differ in their object of choice (in action) and presumably also in their object of fear and confidence (cf. Eudemian Ethics 1229b21ff). The continent in respect of fear do not handle their fear

\footnotetext{
${ }^{8}$ For reasons having to do with the role of choice in passions and virtue, L.A. Kosman reaches a similar conclusion in "Being Properly Affected" (Rorty, Ibid, especially pp 107-111).

9 There is here a further distinction within continence, between endurance and a restricted notion of continence. The latter resists pleasure, the former conquers pain. Since that subtlety does not bear on the present project, I shall concern myself with the wider notion of continence which includes endurance.
} 
well or master it (1149a1) in the sense that they must battle continually with the passions, but do (handle it well and master it in the sense that they) emerge victorious; the incontinent in respect of fear likewise do not handle their passions well and continue to battle the them, but emerge defeated.

Yet a problem in the account is emerging. Aristotle's placement of fear in courage together with what appears to be the force of the doctrine of the mean seems to put at risk the distinction between the courageous and the continent in respect of fear (who must struggle with their passions). Since courage is a mean regarding certain passions, and since a mean state involves feeling at the right time, etc, which we have interpreted as meaning that the passions are to be felt on the field of battle, the habituation and display of courage would seem to require struggle. For if there is no such struggling and mastering, the habituation of these passions looks futile, and not at all like the strength analogy that Aristotle offers (above). The presence of passions such as fear seems to require that one steel oneself against them, thereby making the character trait that is to handle it one of moral strength. ${ }^{10}$ The very struggling with and stealing oneself against the courageous passions suggests the "courageous person" is really one who endures, the continent. ${ }^{11}$ Excluding such passions from courage might seem to avoid this difficulty but creates a different problem by running contrary to Aristotle's claim that virtue involves these passions. ${ }^{\mathbf{1 2}}$ For differing reasons Aristotle is being driven to the claim that

10 It might seem that while the courageous develops their virtue by struggling with feelings of fear and confidence, the attainment of courage should put an end to these struggles. Yet ending such struggles seems to go against the tight connection between the habituation and manifestation of virtue, noted above. Moreover, what precisely that might come to is unclear. What one learns by habituation is either how to handle one's fear or the banishment of said fears. Somehow the courageous person's fears are well handled and not struggled with or perhaps transcended.

11 One could suggest that the courageous have fears and confidences unlike that of the continent's inasmuch as they do not have to struggle with them. That doesn't seem to account for the habituation with respect to the passion. Moreover, without a good deal more said, this makes virtue sound like a matter of luck with respect to fears, and it fails to respect the health analogy. Still, we shall see that there is something right about this suggestion.

${ }^{12}$ Notice that this problem is not solved by maintaining that the courageous do feel these passions, but not on the battlefield. For the tension discussed is found not simply on the occasion of courage's manifestation, but throughout the entire structure of the virtue. 
the courageous feel certain passions and that they are not moved by those same passions. This problem for Aristotelian thought is not new. W.D. Ross suggests that virtue is a matter of controlling instincts; H.H. Joachim takes Aristotle's account of courage to be very much a matter of controlling and enduring fears. ${ }^{13}$ Both, in effect, abandon the virtue-continence distinction by rendering virtue a form of continence. Other options are available: passions could be eliminated from the account of virtue; perhaps the idea of the mean could be set aside.

Yet preserving coherency in the conception of courage in any of the these ways is achieved at the cost of abandoning the core of the Aristotelian analysis of courage, and Aristotle's genuine insights into the phenomenon. Aristotle's point about a role for passions in virtues seems warranted, as is his identification of the relevant passions. That a person enjoys being moderate with regard to bodily appetites is a sign of that person's temperance (1104b4- 7); that a person enjoys giving for its own is a sign of that person's generosity (cf. 1120a25-31); that courage has to do with fear and confidence seems right. Equally, Aristotle's distinction between the continent and virtuous (or, perhaps better, excellent) seems valuable. That people develop themselves in such a way that leading a good life is accomplished without internal struggle indicates something about their character not found in one who leads a similar life but one full of struggle. ${ }^{14}$ Abandoning the doctrine of the mean is the alternative most attractive to moderns. But it is not clear how doing so solves the present problem. Furthermore, I would suggest that when the doctrine is not caricatured, and understood as one giving an account in outline (1103b34-1104a10), then the claim that virtue is a state that results in certain passions and actions at the right time... is perfectly sensible.

\footnotetext{
${ }^{13}$ W.D. Ross, Aristotle, pp 204, 206; H.H. Joachim The Nicomachean Ethics, p. 118. D. Pears in "Courage as a Mean," (Rorty, Ibid), considers how Aristotle can be freed from the predicament of making courage a form of self-control, as does Duff (Ibid).

${ }^{14}$ Whether we would want to deny virtue to the latter sort, or endorse instead a "full" versus "partial" virtue distinction seems arguable. Aristotle himself has some question about how to characterize the difference (1145b1-2). However that goes, Aristotle is right in seeking some sort of excellence-continence distinction as revealing of moral character, and in thinking that the role
} 
I take it, then, that different theoretical concerns of Aristotle tend to lead to different conceptions of how the courageous feel on the battlefield. There is good reason to give fear a role in courage; there is equally good reason to respect some form of the virtue-continence distinction. Yet the latter distinction looks to be at odds with assigning fear its role in courage. Answering the question of what the courageous feel when acting courageously therefore becomes quite important to the Aristotelian: it has far-reaching implications for some of Aristotle's central ethical doctrines or for their interpretation.

\section{II}

To offer an explanation of why Aristotle should be turned in different directions, is not to show that he is so turned. Looking closely at Aristotle's remarks on the role the passions take in courage will allow us to see whether he is, and whether the explanation offered above applies.

Given some form of a virtue versus continence distinction, we should expect Aristotle to hold that the courageous parallel the temperate or generous by being ones who enjoy or are not disturbed by battle, not ones who fear. Our expectation is met: Aristotle suggests that courage is to be either feelingless or positively pleasant when he is expounding how the passions act as indications of virtue. After suggesting that the temperate delight in abstaining from bodily pleasures, he says:

....and he who stands his ground against things that are terrible and delights in this or at least is not pained is brave, while the man who is pained is a coward. (1104b7- 9)

This is not an isolated remark. Shortly afterwards, Aristotle takes up the role fear has in courage. Aristotle seems to be considering the wide scope given to courage by Plato in the Laches. He notes the range of fears humans are subject to, and claims that some fears are appropriate to humans, though inasmuch as one resembles the strictly courageous, one is without fear.

of feelings is relevant to that distinction. 
Now we fear all evils, e.g. disgrace, poverty, disease, friendlessness, death, but the brave man is not thought to be concerned with all; for to fear some things is even right and noble, and it is base not to fear them --e.g. disgrace; he who fears this is good and modest, and he who does not is shameless. He [the shameless] is, however, by some people called brave, by a transference of the word to a new meaning; for he has in him something which is like the brave man, since the brave man also is a fearless person. (1115a10-16)

Aristotle goes on to restrict the domain of courage to concern the evil things that is most frightening, namely death. Yet not even all deaths.

Properly, then, he will be called brave who is fearless in face of a noble death, and of all emergencies that involve death; and the emergencies of war are in the highest degree of this kind. Yet at sea also, and in disease, the brave man is fearless... (1115a33-b1, cf. 1117a17-21)

Thus the suggestion that Aristotle should be moved to a view of courageous acts as enjoyable or at least fearless and thereby painless is born out. I suggest that a view of courage as a virtue, akin to our earlier remarks on generosity and temperance, and in contrast with a picture of courage as continence is the theoretical backing to these claims.

Yet Aristotle's general position that courage is a mean when combined with the most plausible understanding of the mean as having to do with the right time, place, etc. should move him to rather different placement of fear. Indeed the above commitment to fearlessness in courage is not long lasting. A few lines later, after recognizing that what is frightening is not the same for everyone, Aristotle notes that there are some things which are frightening for all those with sense (1115b8). As the analysis proceeds, and as one should expect, the courageous is one with sense. Therefore, the courageous must fear.

This position is soon strengthened.

Now the brave man is as dauntless as man may be. Therefore, while he will fear even the things that are not beyond human strength, he will face them as he ought 
and as the rule directs, for honour's sake; for this is the end of virtue. (1115b10-14)

Not only is Aristotle committed to the courageous feeling fear, but also (and most interestingly) his concern with fears that are and are not "beyond human strength" makes fear very much something to be struggled with and overcome. Thus while Aristotle's remark here about fear quite naturally follows from his doctrine of the mean, as we have anticipated it makes courage sound more like endurance than virtue. Perhaps this explains why the admission of fear in the passage above seems somewhat grudging, and highly restricted. Aristotle may be aware that granting a place for fear seems to go against his previous considerations or his theoretical framework; yet the place for fear is not to be denied. In any case, he has given up the fearlessness or pleasantness of courageous acts, moving to a place for fear in the courageous acts.

Soon afterwards, Aristotle observes that an excess in fearlessness such that one fears nothing is the mark of a madman or one insensible to fear (1115b25). Later, when thinking about the pleasures and pains of courage he says:

Though courage is concerned with confidence and fear, it is not concerned with both alike, but more with things that inspire fear; for he who is undisturbed in face of these and bears himself as he should towards these is more truly brave than the man who does so towards things that inspire confidence. It is for facing what is painful, then, as has been said, that men are called brave. Hence also courage involves pain, and is justly praised; for it is harder to face what is painful than to abstain from what is pleasant. (1117a28-35, my emphasis)

After mentioning various pains the courageous may have to face, Aristotle notes that courage's structure is somewhat unique. He says:

It is not the case, then, with all the virtues that the exercise of them is pleasant, except insofar as it reaches its end. (1117b15-18)

The picture of courage involves fear, painful events. It suggests the continent who struggles not to be disturbed by pain and fear rather than the virtuous (cf. 1115b18-20, 
1104a21-23). One seems to be fighting and coming to terms with painful feelings of fear in the face of death. ${ }^{15}$

Our speculation that Aristotle would be turned in different directions with regard to the passions' place in courage is realized. Moreover, his discussion of the virtue, and our considerations of the theoretical basis for it, put us in a position to see why this is so. (Carelessness or inattention have little to do with it.) Our next task must be to consider the extent to which these problems can be alleviated, and whether Aristotle himself comes to terms with them.

III

One possible way of alleviating the tension is to hold that the conflict is superficial: insofar as one is courageous (and thereby engaged in something noble) one enjoys being so or at least is not pained by it, while insofar as the situation is dangerous one can make room for a moderate amount of fear and pain.

There is something to this suggestion. In the penultimate quotation, the pain spoken of concerns the danger and blows one may receive; the lack of disturbance can plausibly be credited to a concern for the noble. In the last passage, Aristotle admits that the former tends to predominate and that only a successful completion of the act is pleasant. Still, there are difficulties. Earlier claims that courage should be pleasant or feelingless seem to be remarks about the pleasures and pains of acting courageously, not about facets of the state: they seem to exclude the possibility that the state or a facet of it is painful. Waiving this, the proposal still leaves courage requiring self-control. For the fear and the pain remain. The courageous may be undisturbed in the face of them, but that lack of disturbance seems to emerge from mastering and controlling these passions. To this extent, the proposed solution relocates rather than resolves the

\footnotetext{
${ }^{15}$ At 1116 a9 Aristotle comments upon the feelings of the courageous in a way that most directly deals with the question raised at the opening of this paper: he says that the courageous are calm (hesuchia) before battle, but keen, passionate (okseis) in battle. I take this to speak of the generalized effect of the relevant passions (pathe $)$ and, perhaps, the behavioral disposition of the
} 
problem. $^{16}$

A variation along these lines is offered by Aristotle in the Eudemian Ethics.

Shortly after distinguishing what is frightening absolutely, versus what is frightening to a person but not absolutely, he says:

What, then, a coward as such fears is not frightening to anyone or but slightly so; but what is frightening to the majority of men or to human nature, that we call absolutely frightening. But the brave man shows himself fearless towards these and endures such things, they being to him frightening in one sense but in another not -- frightening to him qua man, but not frightening to him except slightly so, or not at all, qua brave. These things, however, are frightening, for they are so to the majority of men. This is the reason, by the way, why the habit of the brave man is praised; his condition is analogous to that of the strong or healthy. For these are what they are, not because, in the case of one, no toil, or in the case of the other, no extreme, crushes them, but because they are either unaffected absolutely or affected only to a slight extent by the things that affect the many or the majority. The sick, then, and the weak and the cowardly are affected by the common affections, as well as by others, only more quickly and to a greater extent than the many,. .. and further, by the things that affect the many they are wholly unaffected or but slightly affected. (1228b24-37)

Not only is there an appeal to facets with the qua distinction, but also the picture of the courageous is of one who most endures and resists human fears --though not to the extent that he becomes unaffected by them: they still affect him slightly.

Although the proposal in this passage deals with the tensions discussed in the most

courageous, rather than a comment about a particular passion.

${ }^{16}$ Pears' analysis (Ibid, p. 181) suggests that a medial desire to avoid death does not need control because it contributes to action. Concerning fear, this would seem to mean that the inclusion of the painful part is not a relocation of the problem because that pain contributes to action rather than requires control. Talking of medial or proper fears here is linguistically satisfying, but the account needs to be filled out before we can tell whether it is truly adequate. For just how fear can be proper, just how the pain can be contributory, not detrimental, is at issue. 
satisfactory way seen so far, still the underlying problems remain. Aristotle cannot view courage as without fear, because that would go against his doctrine of the mean. But with fear introduced, preventing courage from becoming a form of self- control becomes problematic. Here the strategy has to do with qua talk, and minimizing the fear. The qua talk, we have seen relocates the original problem. Minimizing the fear, and therefore, making the degree of self-control needed minimal though reducing the tension, doesn't dispel it. Furthermore, although we have made sense of Aristotle's suggestion that courage aims at the pleasant (1117b1), nothing yet explains his remarks to the effect that courage itself is pleasant.

Although the passage doesn't resolve the problem, I think that the direction of a solution is beginning to emerge. What has bedeviled accounts so far is that in admitting fear, courage is turned into a form of self-control. The reason for this is that the passions have been depicted in a way reminiscent of the Republic and Phaedrus: they are to be grappled with, struggled against and overcome, in much the way of the continent's bodily passions. Such a view of the passions is neither surprising nor inappropriate to much of life. Yet is it necessary that this is the view to be taken of the place of fear in courage, thereby transforming the excellence into continence?

Certainly, the doctrine of the mean doesn't itself require struggle. Consider Aristotle's remarks when distinguishing passions, faculties, and states. ...we stand badly if we feel it violently; or too weakly, and well if we feel it moderately; and similarly with reference to the other passions. (1105b26-8) More relevantly, notice what he says of fear.

Of the faults that are committed, one consists in fearing what we should not, another in fearing as we should not, another in fearing when we should not, and so on; and so too with respect to the things inspire confidence. The man, then, who faces and who fears the right things and from the right motive, in the right way and at the right time, and who feels confidence under the corresponding conditions, is brave; for the brave man feels and acts according to the merits of the case and in 
whatever way the rule directs. (1115b15-19)

Apparently the passions, unlike the continent's bodily appetites, are not simply something to be whipped into line --though they can become that too. Felt in the right way their role is quite different.

Now it is natural enough when thinking about fear experienced upon the field of battle to lose track of this; perhaps that is what has happened in some of Aristotle's foregoing remarks. Nevertheless, that Aristotle allows for a view of the passions in which they are thoroughly appropriate may help to dispel the tension. For if fear can be destructive and require control, it still remains plausible to suggest that it can be of advantage, and is so essentially. Indeed, the inherent goodness of these passions is a view that a philosopher who holds to formal and final causes, and connects these with the good should be disposed to. ${ }^{17}$ Further, when one recalls that confidence is another passion relevant to courage, the prospect that the passions can facilitate, not simply hinder the courageous also looks promising. ${ }^{18}$

The promise is that such a view will dispel much of the tension that we have diagnosed. For if the role of the relevant passions, at least in some of their manifestations, is construed as something that facilitates or contributes to courage, then that creates a structure parallel to that of temperance and generosity. The model becomes one of excellence and no longer that of continence. The doctrine of the mean with regard to the passions has been respected, both in giving a proper place to the

\footnotetext{
${ }^{17}$ Were passions themselves excesses or deficiencies, there would be no commitment to their inherent goodness. Yet Aristotle doesn't indicate this, but that they can be felt too little and too much.

18 At various points we have talked of the proper "handling" of passions such as fear. The handling, so far, has been on the model of something too hot to handle, something with which to struggle as the parts of the soul struggle in Plato's Republic, Phaedrus, and Timaeus (42a3-b1). Often Aristotle is drawn to that Platonic picture. The last two passages, however, suggest that it is their excess and defect that is of this nature. When passions are felt in the right way, at the right time..., perhaps the handling of them is to be understood in a different way. In line with Pears' suggestion (cf. note 16), no longer is fear something for the courageous to control, but something for the courageous to exploit, because, in some way, they facilitate the virtue. How they do this remains obscure, so far.
} 
relevant passions, and in maintaining the view that debilitating effects come about through their excess and deficiency. The courageous will fear in the right way; fearing in any other way will remove us from paradigmatic virtue; vice, continence and incontinence will have to do with excess and deficiency. What these suggestions do not seem to account for is Aristotle's claim of the fearlessness of courage and his placement of pleasure in courage --though perhaps the latter can be explained in terms of confidence. $^{19}$

\section{IV}

To claim that Aristotle develops such thoughts in his ethical writings or that such a picture consistently underlies his writings would be to ignore much that the foregoing discussion brought forward. My claim is more modest: there is to be found in Aristotle a conception of the relevant passions which provides a coherency in the account of courage not otherwise available. I shall argue that Aristotle is seriously committed to a view of the relevant passions as facilitators. It becomes a very attractive understanding of Aristotle if I can show that the view is relatively well developed, and well adapted to Aristotle's depiction of courage.

The popular (and Platonic) depiction of fear as expectation of evil (prosdokian kakou, 1115a10, cf. Laches 198b8-9, Protagoras 358d6) is of little use in this project: it is too general in nature to offer much of an account of how fear encourages and facilitates courageous acts. We need to look elsewhere.

The Rhetoric contains Aristotle's most sustained thoughts on the passions. While his concern in this work is how the passions bear on persuasion, much that he says is beneficial to us. Of fear he says:

Fear may be defined as a pain or disturbance due to imagining some destructive or painful evil in the future. For there are some evils, e.g. wickedness or stupidity,

${ }^{19}$ One might suggest that Aristotle intends by the fearlessness of courage, the lack of excess of fear. That however is a most implausible gloss upon the relevant passages (but see Pears p. 178). 
the prospect of which does not frighten us: only such as amount to great pains or losses do. And even these only if they appear not remote but so near as to be imminent: we do not fear things that are a very long way off; for instance, we all know we shall die, but we are not troubled thereby, because death is not close at hand. ${ }^{20}(1382 \mathrm{a} 22-27)$

According to Aristotle, fear provides significant information about our surroundings, the imminence of painful or destructive evils. If the Eudemian Ethics is brought to bear here, these evils have to do with death (1229a36-b1). To be moved to fear, then, involves the acquisition of certain sorts of information about our surroundings. The information in question is quite specific.

It follows therefore that fear is felt by those who believe something is likely to happen to them, at the hands of particular persons, in a particular form, and at a particular time. (1382b33-3a1)

What Aristotle claims for fear, then, is a mechanism sensitive to and focusing upon certain sorts of information, leaving persons moved to fear with very specific conceptions of how their surroundings relate to them. To use a contemporary way of speaking about this, fear identifies certain features of our world as salient ones. In this alone fear is to be seen as something beneficial for making one's way about in the world. Earlier we saw that the fears relevant to courage had to do with a noble death (1115a30-35). Since fear offers information about painful, destructive evils, the arousal of fear provides information particularly relevant to someone on the field of battle who is set to act

Rather Aristotle seems too attracted to the platonic-continent view of the passions at points. ${ }^{20}$ Some points about translation are in order here. As W.W. Fortenbaugh has pointed out (Aristotle on Emotion, pp. 12-16) when Aristotle say that fear is a pain 'due to' (ek) certain imagined evils, he cites the cause that is a component of fear rather than something separate from it. Further, the term translated 'imagining' (phantasia) ranges in meaning from an image, to a phantom, to a display or displaying. The translation could be misconstrued --especially in light of certain appearance-reality dichotomies-- as entailing that fear is driven by phantoms of our imagination. The dichotomy is contrary to the Greek view of appearances, and Aristotle's discussion of fear does not run along such lines. Rather the point is that fear is driven by the presentation or appearance of destructive and painful evils. A parallel point applies to the use of phantasia in the definition of confidence, to follow. 
courageously. Thus the arousal of fear should facilitate such noble action. Moreover, the significance of what fear presents to the courageous in the circumstances of courage and its usefulness thereby is further underscored when one recalls that Aristotle takes our ultimate goal to be living and doing well (1095a16-22).

Fear concerns matters particularly relevant to us, things to be dealt with immediately. For fear's scope is not any painful or destructive evil, but only those imminent (above, cf. Eudemian Ethics 1229b15-17). That imminent, destructive or painful evils be salient features is perfectly appropriate, again, especially given fear's role in courage - and therefore on the battlefield.

Further, fear seems a very sensitive information source.

Hence the very indications of such things are terrible, making us feel that the terrible thing itself is close at hand; and this --the approach of what is terrible-- is danger. ${ }^{21}(1382 \mathrm{a} 30-2)$

Viewed in these ways, fear is not something to be struggled with or overcome, but something to be sensitive to and exploited. The prospect of imminent, destructive or painful evils that fear embodies is particularly important to a creature whose ultimate aim is to live and do well. Fear on a battlefield then involves an awareness of the situation with which one has to deal, and does so in a way that allows one to prepare to deal with the situation. Feeling fear enables one to act courageously.

Yet Aristotle does not offer fear as an unimpeachable channel of information. For it tells us of the appearance (phantasia) of destructive or painful evils; it is kindled at the very indications of terrible things. ${ }^{22}$ Thus while fear often anticipates and informs us of important evils, it would seem that it sounds the alarm falsely at times. For the indications may arise but not the indicated; appearances may not be realized. The value of fear seems thereby diminished.

This difficulty is real, but it is ameliorated when one considers the circumstances

\footnotetext{
${ }^{21}$ Here and elsewhere 'terrible' can be rendered 'fearful'; 'terrible thing, 'fearful thing.'

${ }^{22}$ For thoughts on how passions can construe the same circumstances in different ways see
} 
of fear and courage. The situation envisaged is the field of battle. Circumstances of danger, like much else, are not always clear-cut (cf. 1116b5-10). Since fear discharges at the very prospect of evil and danger, it anticipates evils and dangers. As such, it provides an early indication of the approach of the fearful, which should allow one to prepare for those evils and dangers in a way not possible were fear to discharge only when dangers become glaring — which in certain cases would be too late a notice. Thus while fear may have one needlessly roused and preparing, on the whole that seems to have greater benefits than a comparable mechanism that would wait until the evil became perfectly clear. Once again, fear facilitates courageous action.

Fear is not simply a matter of perception or the channeling of information. Fear is a painful event in our lives. As a form of distress, fear serves to draw attention to itself and thereby the information it provides. Notice must be, or is more likely to be, taken thereby. By drawing attention to itself and salient features of the world it presents, fear functions to warn us regarding information that is of utmost importance to our flourishing. Fear then warns the person on the battlefield; it doesn't allow the relevant information to be taken in yet be neglected or dismissed. As such it helps ensure that the person prepare for that of which it warns; it promotes courageous action.

The pain of fear has a function beyond warning us. For Aristotle pain involves wanting (De Anima 413b16-24. cf. 414a32ff) and avoidance (De Anima 431a8-10). By being painful, then, fear is itself a motivational force and undertaking which makes us avoid the source of fear's concern, painful or destructive evils. ${ }^{23}$ Hence fear motivates and sets in motion the courageous in an appropriate way. Of course, cowards also avoid painful and destructive evils. But in this alone there is no error: error arises in avoiding

section of one "Aristotle and the Emotions" by S. Leighton (Phronesis, 1982).

${ }^{23}$ Although fear's definition doesn't mention a desire (unlike anger's), it is accounted for here via the pain of fear. This placement is supported further inasmuch as desire seems a natural reaction to the prospect of painful and destructive evils from a creature capable of desire. As well, Aristotle's claim that fear requires hope of escape, a notion that seems to presuppose an end to be sought, likewise indicates a role for desire. Since fear itself involves activity, at those junctures the action-passion contrast virtue concerns is not one of different fields. 
these evils at the cost of the noble, in fearing and avoiding these evils excessively.

Because his interest is in persuasion, Aristotle does not find it useful to discuss the role of the body in the passions in the Rhetoric, but elsewhere he makes it clear that no definition of a passion could be adequate unless it included the body's role (De Anima 403a16-19). Given what he says there, it seems reasonable to assume that fear involves bodily upset. If so, the stirring of the body should further prepare one for and enable courageous action, as one finds in one's physical reaction to a sudden fright.

According to the Rhetoric, fear makes us think about what is to be done (1383a6-7). This claim, while contradicting thinkers such as Gorgias who hold that fear expels thought, is but an instantiation of Aristotle's analysis of the passions as those things accompanied by pleasure and pain that alter judgment (1378a20-23). Thus the person feeling fear considers what is to be done, and, given the place of the noble, done best. The benefit of this for the courageous is that by virtue of being moved to fear, one is determining strategies for dealing with the things which require the exercise of courage. Here again the passion facilitates rather than inhibits courageous action.

Fear's value isn't for pondering, say, one's ultimate demise (remote evils), instead it assists us in coming to grips with a world (taken to be) pressing upon us. It is, then, something particularly appropriate to the circumstances of courage's manifestations. The Rhetoric qualifies this in interesting ways. Where there can be no hope of escape (1383a7) or where one sees oneself open to no harm either because one can resist it (1382b33) or because one has already suffered every kind of horror and has grown callous to the future (1383a3), fear won't arise. Thus the functioning of fear is curtailed where one is so beaten as to see no chance for dealing with the situation, or so optimistic as to see no prospect of harm. ${ }^{24}$ In these circumstances courage holds no value; fear, no use. Only those who take themselves to be in a position not admitting of change, totally

\footnotetext{
${ }^{24}$ Arguably, Aristotle should rethink the point about fear not arising where there is no thought of escape in light of examples such as the battle of Thermopylae, and speak instead of no thought of attaining the noble (cf. 1116b15ff). Perhaps, however, tragic examples are no longer ones of paradigmatic fear or courage. (cf. Pears on desperate and sperate courage, Ibid, p. 183.)
} 
beaten or natively unrealistic will find themselves upon the battlefield without fear; thereby all these will be without courage in any strict sense. In contrast, fear is bound up with a view of a future that is deemed uncertain but not without hope. Fear on the battlefield involves a perspective upon one's situations from which courageous action can be undertaken, and without which courage in a strict sense is not possible.

The picture that we have arrived at is one in which fear serves as a channel of information, information particularly pertinent to our well being, and information that is particularly pressing at the moment. Further, fear is to be construed not simply as a conduit of such information, but also as a warning that the information can't be ignored, but needs to be acted upon. Again, it provides the motivation, stimulates the thinking, and engages us in the action we need in order to deal with the circumstances of which it warns. And since its concern is the noble, it does so in a way that facilitates courageous action. On this understanding of fear, not only is there little wonder that Aristotle should think that the courageous fear, but also little surprise that this passion should help define the state as an excellence rather than a form of self-control. Fear, so conceived, is not like the continent's bodily appetites with which one must struggle and overcome, but rather something that is of great assistance to the courageous, something to be sensitive to and exploited. This understanding of fear in courage better parallels the pleasure of generosity than the pain of hunger. So understood, fear is a sign of virtue, not continence. It is in its excess or deficiently, in being aroused when not warranted or too easily, or not enough, etc. that fear becomes a matter of continence or vice.

We see, then, how fear itself is something of value such that it need not be struggled against, but exploited. Further, I have indicated that and how this exploitation is particularly beneficial to the courageous upon the field of battle. This allows Aristotle to offer a conception of the virtue courage which does justice to our experience by not denying fear a place, yet does so in a way that 1) allows the state of character to be a full fledged virtue, not simply a form of self-control, 2) respects the doctrine of the mean, and 3) does not require bizarre notions of fear or courage. If so, Aristotle's moral framework 
is intact. ${ }^{25}$

But we cannot claim to have succeeded in restoring harmony to all of Aristotle's remarks. The passages in which he down-plays a role fear, the remarks which suggest the courageous control or struggle with fear, and the developmental analogy between strength and courage do not fit the paradigm of courage. To the extent that one can interpret some of these passages as objecting to the excess or deficiency of the passion, one gets consistency throughout. Yet where Aristotle is doing more than this, where he is denying the passions to the courageous or requiring that we overcome them, we shall have to say that he hasn't appreciated some of his own insights, and is thinking of fear a little too much along the lines of the gluttons pleasures and pains. ${ }^{\mathbf{2 6}}$

\section{$\mathrm{V}$}

These conclusions are significant. For we now know that passions can be fitted into the account of courage without harming any significant moral positions of Aristotle. So far, I have given little thought to confidence. Does confidence fit in equally well?

Placing confidence into the picture of courage is more difficult. Aristotle's thoughts on confidence in his ethical writings seem to be entertained largely out of deference to traditional wisdom and Plato, rather than any deep commitment; they are regrettably brief, and undeveloped. The situation of the Rhetoric is only marginally

25 Although there is much in Duff's analysis that I agree with, some differences can now be noted. Whereas Duff thinks that fear's role on its own requires resistance and overcoming, i.e. self-control (cf. pp. 5, 6-7), I have tried to show that fear is properly an active part of excellence. Relatedly, whereas Duff feels that fear must be transformed by confidence before it can partake of excellence, my account of fear requires no such transformations . Again, whereas Duff concentrates on those who see their safety as unlikely, in particular the martyr who sees no hope of survival (cf. pp 12-15), I consider what I take to be the paradigmatic case of the courageous, one who realizes the real possibility of death, but remains hopeful of better results (cf. 1115a32-b5, 1383a7)). Further, whereas Duff's considerations are meant as a plausible account of courage in an Aristotelian spirit (cf. p. 2), I have attempted to use an explication of the Rhetoric on these emotions to solve the problem.

${ }^{26}$ At bottom the difference between the two has to do with the passions being reasonable, whereas the appetitive desires are not so. See "Aristotle and the Emotions" (Ibid, pp. 161-3,) for more on this. 
better.

Confidence is said to be the opposite of fear; its causes are opposite as well (1383a15).

...it is, therefore, the imaginative expectation of the nearness of what keeps us safe, and the absence or remoteness of what is terrible: it may be due either to the near presence of what inspires confidence or the absence of what causes alarm. (1383a16-20)

Aristotle's characterization seems to embody two notions of confidence, one useful for the paradigm of courage; the other, useful for courage in an extended sense.

Aristotle's talk of hope or expectation (elpis) fits in well with what he has had to say about fear. Fear requires hope (elpis) of escape (1383a7); confidence specifies more particularly what should be hoped for, safety. Fear gives the courageous an object of aversion; confidence, an object of desire. ${ }^{27}$ We saw that fear makes one think about what is to be done; confidence sets out more precisely what is to be done.

These points about fear and confidence may seem trivial: determining such ends of desire is no remarkable accomplishment. Still, when it is recalled that the situation of courage is the danger of the battlefield, we can see a function served by the arousal of confidence and fear. They short-circuit hesitation and reflection, and have one seeking goals relevant to a pressing situation. Where one has the luxury to ponder, these passions will be of little value, but since that is not the situation of the courageous, the

27 Pears' analysis of confidence by-passes a place for desire, concentrating instead upon calculation of odds (Ibid). However, if, as I have suggested, confidence's hope for safety is a further targeting of fear's hope for escape, then, given the plausible analysis of fear's hope for escape as involving a desire to escape, it seems that confidence's hope for safety should involve a want to attain that safety.

At 1116a3 Aristotle says that confidence is the mark of a hopeful disposition. It seems that the grounding of confidence is hope, and that whatever value confidence may have depends, in large measure, on the value of hope. It seems likely that what is hoped for should involve the idea of the noble. If so, I find myself in agreement with Duff and in contrast with Pears in thinking that confidence, like fear, is concerned with the noble. Unlike Duff, however, I do not see that Aristotle has said anything which commits him to the view that confidence must account for the noble. 
presence of both passions is of value to the courageous to get on to the goals of victory and the noble (1115b23).

Since confidence is said to involve the imaginative expectation (hope) of what keeps us safe, confidence will be roused by the prospect rather than the certainty of what keeps us safe. Like fear, it is less cautious than it might be. Like fear, its value is that it will enable the person on the battlefield to prepare for dire situations better than if he to wait for everything to become clear. Here too the manifestation and activity of the emotion may prove unjustified. Here too that seems a better consequence, given the circumstances, than the dangers inherent in a later arousal.

The source of confidence is said to be the near presence of what inspires confidence. The end sought must be in sight and possible to realize. Thus the hope for safety is not foolish, but a reasonable one on the part of the courageous, given knowledge of their own abilities, the assistance available, etc. ${ }^{28}$ Once again, having confidence is desirable and something likely to facilitate rather than hinder the courageous. Fear and confidence seem complementary in their role of aiding the courageous in courageous action.

As the sentience of fear added urgency to the situation, so the possible pleasure of confidence could facilitate action. ${ }^{29}$ For on Aristotle's view activities are better done if done with pleasure than otherwise (1175a30-36). Furthermore, the possible pleasantness of confidence could account in a way more satisfactory than so far seen for

\footnotetext{
28 This hope must not be reduced to experience of the facts (1116b1ff), to the passion seen in wild beasts (1116b22), to the sanguine (euelpidos, 1117a10) who think they are the strongest and can suffer nothing, to those ignorant of their situation (1117a23). Duff seems to take those who face danger with the expectation (hope) of safety to be ones who display experience or a sanguine spirit (Ibid, p. 9). As suggested already, I do not see that Aristotle has an automatic move from hope for safety to sanguinity.

29 Aristotle doesn't mention the sentient content of confidence, though his general characterization of passions (1383a20-23) suggests that there is one. If there is one, it would seem likely that confidence is seen as a sort of pleasure --though possibly it is the keenness spoken of in note fifteen. Yet whether confidence does have a sentient content remains controversial. (See M. Woods Aristotle's Eudemian Ethics, a translation and commentary Oxford University Press, 1982, especially pp. 109-111; S. Leighton "Eudemian Ethics 1220b11-13" Classical Quarterly
} 
Aristotle's claim that courageous action is pleasant.

As with fear, it is reasonable to suppose a bodily component involved in confidence. If so, the stirring of the body, which is felt by the confident will help to enable them to act in accord with their emotion.

The foregoing characterization of confidence harmonizes with our account of fear and the role we have found for the passions in courage. It fits with the requirement that courage be viewed as an excellence, not a form of continence.

Yet other aspects of Aristotle's thought on confidence fit less well. I take this up, not so much to answer our opening question (for that has been answered), but to display the currents in Aristotle's thought on this topic.

In his characterization of confidence Aristotle also speaks of (the expectation of) "the absence or remoteness of the terrible" (fearful), and suggests that confidence is due to "the absence of what causes alarm." When speaking of the remoteness of the fearful, Aristotle would seem to have in mind the destructive and painful evils which are objects of fear, including the one especially relevant to courage, a noble death. If so, confidence seems to require the absence or diminution of fear, rather than something that complements fear. Similarly, in speaking of the absence of what causes alarm Aristotle suggests the absence of fear rather than its presence. Here we don't have an emotion separate from fear, but its' polar opposite: the ebb of one is the flow of the other.

Certainly confidence so characterized might be valuable on the battlefield. Being moved to this emotion would help one by revealing that fear is unnecessary: danger does not threaten. This conception of confidence yields a Socratic vision of courage as a matter of knowledge of the facts (1116b4-23), a move in the direction of the idea that knowledge is sufficient for virtue. While the conception of courage implicit in this second construal of confidence diminishes the role of passion by having fear and confidence work to cancel each other, the conception of courage on the first construal

1984, vol 34.) 
keeps both fully active, working towards a common goal. ${ }^{\mathbf{3 0}}$

Which conception of confidence is Aristotle's? This seems to be the wrong question to ask. Aristotle's remarks on confidence suggest both; he does not seem to distinguish the two. Not distinguishing the two is failure, however, only if we are thinking of the relationship between courage, fear and confidence. If we take seriously the fact that the Rhetoric's discussion of confidence is concerned with the question of persuasion, then the differences between the two forms of confidence will not seem so significant. Both set out certain ends and a context within which persuasion must work. It is true that Aristotle's remarks on confidence aren't as helpful as they might be for understanding courage, but then that isn't the goal of the Rhetoric.

Which conception is most helpful in characterizing the courageous? The latter conception works towards a continent and Socratic conception of courage. By rendering the threat of danger impotent, and by making fear superfluous to the courageous, confidence's role conflicts with fear's role in courage. Where there is confidence, there is no fear, and vice versa. Yet we have seen that a role for fear is not to be excluded from the analysis of courage; the danger the courageous face is not to be explained away: fear and confidence need to complement each other. Since Aristotle's interest is to give the paradigm of courage rather than a derivative version, and since paradigmatic courage gives a full place for fear and confidence, the second construal of confidence cannot be accommodated within the analysis of paradigmatic courage and courageous action. It is the former conception of confidence that is most useful for interpreting courage as an excellence in the full sense.

How, then, do the courageous feel upon the battlefield? In the paradigmatic case of courage one is both fearful and confident. The passions are not thought of as at odds with each other or the activity of courage, but rather as complementing each other and

\footnotetext{
${ }^{30}$ What seems to have happened is that the second conception of confidence deals with the same objects had in fear (fearful, alarm) but here negated. In contrast, the first conception of confidence deals with related though slightly different objects (safety, what inspires confidence). As a result, while fear and confidence on the first construal can work together and complement
} 
facilitating courageous action. The passions are to be felt in accord with the mean; that is, at the right time, to the right extent, etc. If they are not felt in accord with the mean, the passions require control and virtue becomes a form of continence. Just what feeling these in excess, deficiently and medially come to is to be explained in terms of the aims and nature of these passions - and part of that explanation is offered in the Rhetoric. ${ }^{31}$

each other, on the second construal, confidence cancels the influence of fear (and vice versa). ${ }^{31}$ I would like to thank M. Schofield for his many helpful suggestions for the improvement of this paper. 